\title{
Cytochemical localization of certain hydrolytic enzymes at various stages of development of Achlya flagellata mycelium
}

\author{
I. PALCZEWSKA, G. JAGODZKA \\ Institute of Biochemistry and Physiology, Dept. of Plant Cytology and Cytochemistry, \\ University of Łódź, Łódź, Nowopołudniowa 12/16, Poland \\ (Received: November 4, 1971)
}

Abstract:

The standard coupling azo dyes techniques were used to reveal the activities of acid phosphatase, alkaline phosphatase, esterase and $\beta$-galactosidase in the vegetative and reproductive cycle of Achlya flagellata.

The end-products of the enzymic reactions, with the exception of $\mathrm{E} 600$ sentisive esterese, which is localized in cytoplasm, occured in cytoplasmic granules. These granules are expected to be spherosomes.

Acid phosphatase activity is high in differentiating sporangia, in antheridial hyphae and in degenerating oospheres where hydrolytic processes occur. $\beta$-galactosidase is the least active enzyme in the mycelium of Achlya.

\section{INTRODUCTION}

In recent years the development of research on enzymes as well as on lysosomes and spherosomes which are carriers of many hydrolytic enzymes, has aroused interest in the localization of these enzymes in fungal cells.

The occurrence of lysosomes, called spherosomes by some authors, have been confirmed by numerous workers who examined various species of fungi by light (Gutz 1956; Palczewska 1964; 1965; Armentrout et al. 1968; Wils on et al. 1970) and electron microscope (B u ckley et al. 1968; Williams and Webster 1970; Wilson et al. 1970).

Biochemical studies on isolated vacuoles (lysosomes) have supplied data on the occurrence in fungi of a large set of hydrolytic enzymes discovered already in animal lysosomes and in spherosomes of higher plants (M atile and Wiemken 1967 - acid and alkaline protease, ribonuclease, esterase and aminopeptidase in yeast cells; I ten and M a til e 1970 — acid and alkaline protease, ribonuclease, acid phosphatase, glucosidase, chitinase in Coprinus lagopus). 
The authors of the so far not numerous papers dealing with cytochemical investigations consider that lysosomes like bodies (spherosomes) are the site of acitvity of the enzymes investigated: acid phosphatase (Pitt and W alker 1967; Pitt 1968; Wils on et al. 1970), esterases (Pitt 1968; $\alpha$ - and $\beta$-glucisidase (R eiss 1969), $\beta$-galactosidase (Pitt 1968; R eiss 1969), acid deoxyribonuclease (Pit t 1968; Re is s 1969) and aryl sulphatase (Wils on et al. 1970).

Only two attempts have been made to detect acid phosphatase by electron microscope in structures which the authors consider as counterparts of spherosomes (lysosomes). W il s o n et al. (1970) localized this enzyme on the surface of lysosomes of Ceratocystis fimbriata and the other species. Buckley et al. (1969), however, consider that positive results obtained in germinating Rhizopus spores are unspecific, because the same type of precipitate occurred on the surface of lysosomes treated only with lead citrate.

G ün th e r (1968) presents on electron micrographs of yeast cells the localization of acid phosphatase in round, oblong or slightly curved bodies measuring $0,2-0,5 \mu$. He does not include these structures into any known group of cell organelles.

The previously mentioned papers dealing with cytochemical research (Pitt 1968; Reis 1969; Wils on al. 1970) give mainly information on the adaptation of cytoenzymical methods to fungal cells. These studies were performed only on vegetative mycelia.

There are no data in the literature on the occurrence of hydrolytic enzymes during differentiation of sporangia and in sexual reproductive cells. In the present paper the activities of the following enzymes acid phosphatase, alkaline phosphatase, indoxyl esterase and $\boldsymbol{\beta}$-galactosidase - have been examined during the development of the fungus Achlya flagellata.

\section{MATERIAL AND METHODS}

The Achlya flagellata strain was initially isolated from a carp infected and grown out in laboratory for several years. Stock cultures were maintained on plates of pepton or hamp-seed extract agar. Vegetative growth was very vigorous on these media. Cultures for cytochemical investigations were prepared as follows - on pepton agar plates with grown mycelia (colonies about $1,5 \mathrm{~cm}$ in diameter) halves of sterilized hemp seeds were placed on the surface of the culture. After the fungus had developed a vigorous growth on the hemp seeds, the latter were transferred to culture dishes with sterile tap water. The mycelium was well developed in $2-3$ days, on hyphal tips sporangia differentiated. Within 8 days branchings with oogonia and antheridial hyphae formed. 
Cytochemical tests were carried out on both fresh and fixed (phosphate buffered formalin at $4^{\circ} \mathrm{C}$ for 1 hour, or 12-16 hours and cold acetone for 1 hour) material. Mycelial mats were placed in incubation mixtures together with seeds to avoid damaging the hyphae, which may easily occur in coenocytic mycelia.

Indoxyl esterase was detected by Holt's method. The incubation time was $30-40 \mathrm{~min}$. E 600 at $10^{-3}$ was used to differentiate organophosphorus - sensitive and resistent esterases. Sodium flouride at $10^{-3}$ was also applied.

Acid phosphatase. Simultaneous coupling azo-dye technique with sodium $\alpha$-naphtyl phosphate as substrate and Fast blue RR salt (incubation time 10 minutes at $37^{\circ} \mathrm{C}$ ), or Burstone's method with naphtol AS-BI phosphate and Red violet LB salt (incubation time 20 minutes at $37^{\circ} \mathrm{C}$ ) were used. Control experiments were performed by omitting the substrates from the incubation media and by using heat-inactivated material ( 5 minutes in boiling water vapour). $10^{-3} \mathrm{NaF}$ was also employed.

Alkaline phosphatase was asseyed either with sodium- $\alpha-$ -naphtyl phosphate as substrate and Fast blue RR salt (incubation 45 minutes at room temperature) or naphtol AS-BI phosphate as substrate and Fast blue RR or Red violet LB salts (incubation 30-40 minutes at room temperature). As control samples were preincubated in $0,1 \mathrm{~N}$ HCL for 1 hour.

$\beta$-galactosidase was demonstrated after $\mathrm{Rutenburg}$ et al., Mycelial mats were incubated for 90 minutes at $37^{\circ} \mathrm{C}$ using 6-bromo-2-naphtyl-D-galactopyranoside. The post-coupling was performed with Fast blue B salt at $4^{\circ} \mathrm{C}$. Control samples were heat-inactivated.

Aryl sulphat a se was localized by using the method of Rutenburg et al. with substrate potassium 6-bromo-2-naphtyl sulphate and coupling with Fast blue B salt at $4^{\circ} \mathrm{C}$.

Cytoenzymic procedures were performed according to $\mathrm{Pearse}$ (1961).

\section{RESULTS}

Observations were mainly based on the results of reactions performed on unfixed material. Pilot tests showed that the localization is similar in both fresh and fixed mycelia however reaction intensity is generally weaker in fixed material. Besides, both fixatives are not ideal for the Achlya mycelium: formalin may cause swelling of spherosomes, destruction of cytoplasm and formation of secondary lipid droplets; acetone causes shirking of the mycelium content. Acetone is a recommended fixative especially for cells containing lipids, and in fact the appearance of acetone fixed hyphae is often quite satisfactory (Plate II, fig. 5). 
Generally not all mycelial fragments show positive reactions: hyphae without reaction products always occur besides those with enzyme reaction end-products. Attempts to measure the amount of hyphae giving a negative reaction showed for example $-20 \%$ for acid and $10 \%$ for alkaline phosphatase. In some hyphae diffuse staining of the cytoplasm was observed but it always accompanied particulate staining. Lipid globules present in the hyphae sometimes stained homogeneously, but the colour of this stain was different than that of reaction product.

Table 1

Results of histochemical localization of enzymes investigated

\begin{tabular}{|l|c|c|c|c|}
\hline & $\begin{array}{c}\text { Acid } \\
\text { phosphatase }\end{array}$ & Esterase & $\begin{array}{c}\text { Alkaline } \\
\text { phosphatase }\end{array}$ & $\beta$-galactosidase \\
\hline Hyphae & ++ & ++ & +++ & + \\
Sporangia & +++++ & ++++ & +++ & + \\
Spores & ++ & ++ & ++ & - \\
Antheridial hyphae & +++ & ++ & ++ & + \\
Undifferentiated & & & ++ & + \\
$\quad$ oogonia & ++ & ++ & +++ & + \\
Oospheres and oospores & ++ & ++ & ++ & + \\
\hline
\end{tabular}

Attempts to detect aryl sulphatase activity were unsuccessful. Other enzymes investigated were present at all developmental stages. Results of histochemical localization of these enzymes are presented in Table 1 . The low $\beta$-galactosidase activity is distinctly noticeable here; in spores this enzyme was not detectable. Its relatively greatest quantities occur in vegetative hyphae. Acid phosphatase activity reaches specially high level in differentiating sporangia. Antheridial hyphae were distinguished also by high activity of this enzyme. Indoxyl esterase was more active in sporangia than in other developmental stages. Alkaline phosphatase seems to be characteristic for vegetative hyphae. In oospheres and oospores the activity of all enzymes examined is low.

\section{Vegetative hyphae}

Mitochondria and spherical bodies $0,2-1 \mu$ in diameter can be distinguished in living somatic hyphae (Plate I, Figs. 1,2). These bodies are distributed uniformly throughout the cytoplasm or may be associated in groups. Their apperance under phase contrast correspond with that of the spherosomes of higher plants. The hyphal tips contain few spherosomes. Their number is greater in older parts (Plate I, Fig. 2), and their diameter is often increased. In some hyphal fragments lipid droplets may occur. The configuration of the cytoplasm undergoes frequent changes as a result of cytoplasmic streaming which may be rather violent in 
coenocytic mycelia. In these regions small vacuoles (Plate I, Figs. 3, 4) and endoplasmic reticulum can be seen.

Particulate localization of all enzymes examined was revealed in vegetative hyphae. In extremal parts of hyphal tips, where spherosomes are absent, no reaction product is visible (Plate II, Fig. 1,2,3,4). In apical parts the enzyme activity is bound with spherosomes which are spherical, small, sometimes of a size above the limit of resolution of the optical microscope. Staining of the spherosomes obtained as a result of tests for $\beta$-galactosidase and esterase is very weak (pale blue).

In older parts of hyphae small spherical spherosomes are stained uniformly (Plate I, Fig. 5,10), but larger ones are deformed and then the stained bodies are cup- or crescent shaped (Plate I, Fig. 6). Coloured products in the form of small granules are also present in the lipid bodies, larger than spherosomes. $\beta$-galactosidase occur in the spherosomes sometimes localized near the cell wall. The number of stained granules is always lower than in the case of acid and alkaline phosphatase (Plate I, Figs. 9,10).

Alkaline phosphatase gives the most differentiated picture of cytochemical localization (Plate I, Figs. 5,6,8).

The reaction product may occur in the form of a very small granules, the localization may be spherosomal, dictyosomes can also be stained. Dictyosomes which were detected by electron microscope in somatic hyphae of Achlya (P a l c z e w s k - unpublished) can not be distinguished unequivocally from spherosomes in stained mycelium, as some of them have the similar diameter. Alkaline phosphatase seems to be the most active enzyme in vegetative hyphae.

Attempts to detect the activities of both phosphatases in the same hyphae using ,double enzymatic staining" did not yield the expected results because of rather deep staining of cytoplasm. However, in some hyphae, after the tests for both enzymes, the number of coloured structures is higher than the number of such structures after reactions for either of these enzymes (compare Fig. 5 and 7, Plate I).

\section{Sporangia}

In 3-days old mycelium a great part of hyphae is densely filled with cytoplasm in which it is difficult to distinguish between particular organelles (Plate II, Fig. 8). These hyphae give rise to sporangia which are borne at the tips and separated by a septum.

During differentiation of the sporangium the dominating enzyme is acid phosphatase (Plate II, Fig. 5). This enzyme is localized in the spherosomes (Plate II, Fig. 6,7), which are slightly enlarged in this stage. The organelle clusters seen in the photograph are the contents of future spores. The acid phosphatase activity is already higher in the apices 


\section{Plate I.}

Localization of hydrolytic enzymes in vegetative hyphae

Figs. $1-3$. Living hyphae in bright field, about $\times 2500$

Figs. 4. Fragment of hypha presented in Fig. 3 under phase contrast, $\times 2500$

Fig. 5. Alkaline phosphatase, acetone-fixed, sodium $\alpha$-naphtyl phosphate, Fast blue $R R$ salt

Fig. 6. Alkaline phosphatase, unifixed, naphtol AS-BI phosphate, Fast blue RR salt

Fig. 7. Double reaction, acetone-fixed: sodium $\alpha$-naphtyl phosphate and Fast blue RR for alkaline phosphatase + naphtol AS-BI phosphate and Red violet LB for acid phosphatase.

Fig. 8. Alkaline phosphatase, formalin-fixed, sodium $\alpha$-naphtyl phosphate, Fast blue RR salt.

Figs. 9, 10. $\beta$-galactosidase, unfixed

Figs. $5-10 \times 2000$

Plate II

Localization of hydrolytic enzymes in hyphal tips and in differentiating sporangia

Figs. 1-4. hyphal tips, 5-11, differentiating sporangia

Fig. 1.Acid phosphatase, unfixed, sodium $\alpha$-naphtyl phosphate, Fast blue RR salt Fig. 2. Alkaline phosphatase, unfixed, naphtol AS-BI phosphate, Fast blue RR salt

Fig. 3. Alkaline phosphatase, formalin-fixed, naphtol AS-BI phosphate, Fast blue RR salt

Fig. 4. Alkaline phosphatase, unfixed, sodium $\alpha$-naphtyl phosphate, Fast blue RR salt

Figs. 5-7. Acid phosphatase, unfixed, sodium $\alpha$-naphtyl phosphate, Fast blue RR salt

Figs. 8, 10. Fragments of differentiating living sporangia in bright field (Figs. 9, 11. Indoxyl esterase, unfixed

Fig. 5. magnified about $\times 500$, others about $\times 2000$ 
Plate I
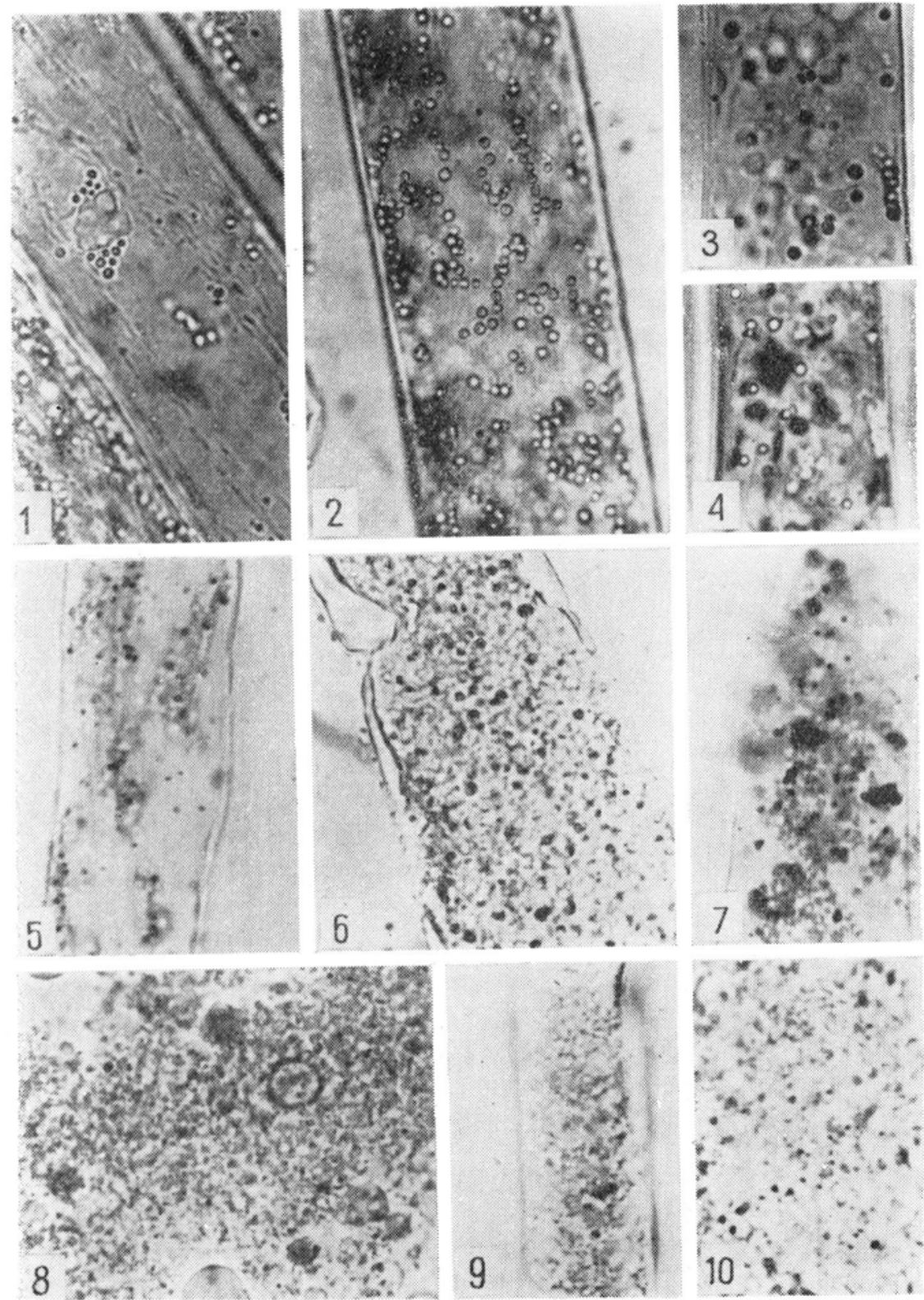
Plate II

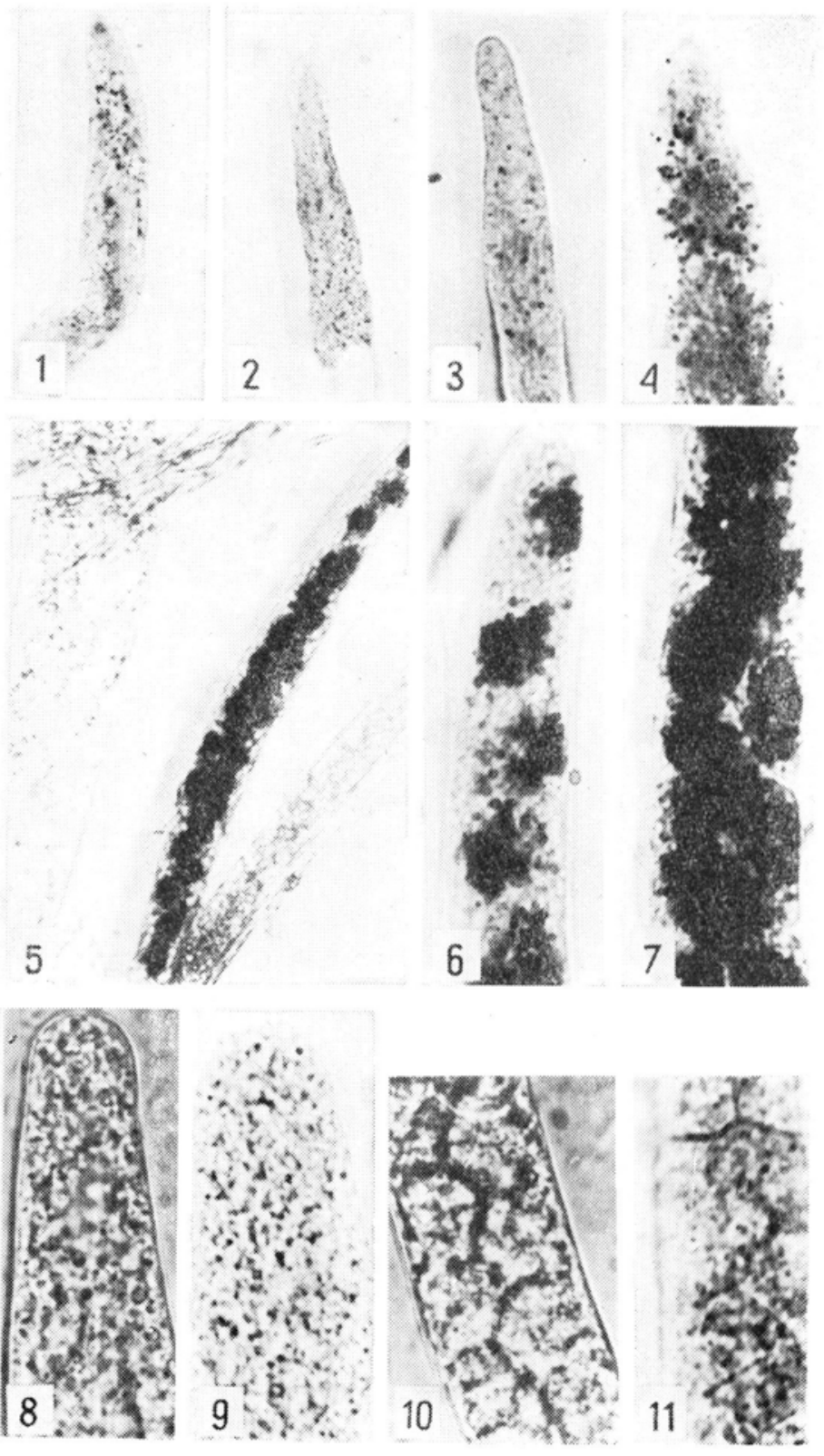



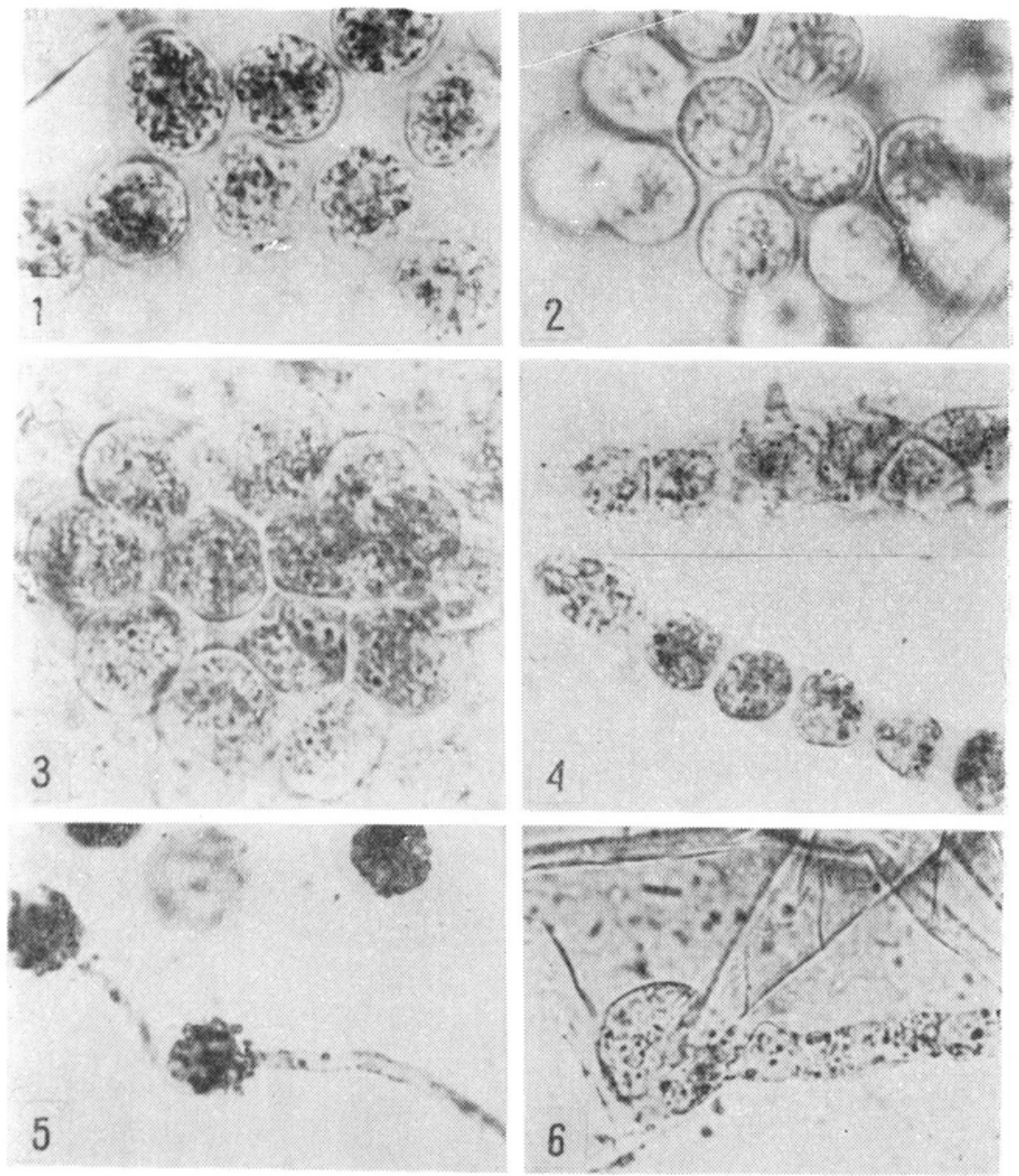

Localization of hydrolytic enzymes in spores

Fig. 1. Alkaline phosphatase, unfixed, naphtol AS-BI phosphate, Fast blue RR salt

Fig. 2. Alkaline phosphatase, control $0,1 \mathrm{n} \mathrm{HCl}$

Fig. 3. Indoxyl esterase, unfixed

Fig. 4. Acid phosphatase, unfixed, sodium $\alpha$-naphtyl phosphate, Fast blue RR salt

Figs. 5, 6. Alkaline phosphatase, unfixed, naphtol AS-BI phosphate, Fast blue RR salt

All magnifications $\times 2000$ 

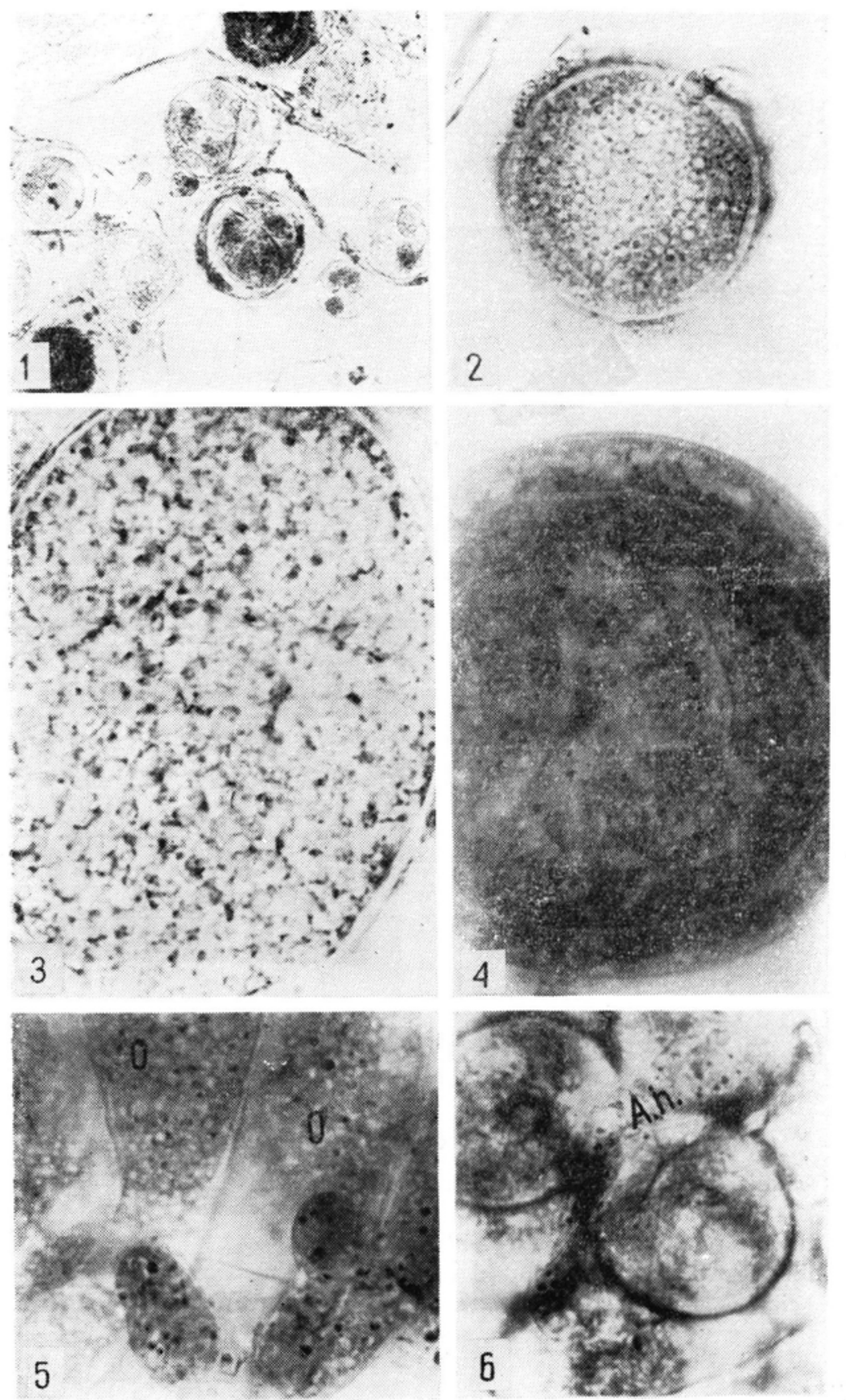

Localization of hydrolytic enzymes in undifferentiated oogonia and in antheridial hyphae

Fig. 1. Acid phosphatase, unfixed, $\times 340 ;$ Fig. 2. Acid phosphatase, unfixed, $\times 9000$; Fig. 3. Indoxyl esterase, unfixed, $\times 2000$;

Figs. 4-6. Alkaline phosphatase, unfixed, sodium $\alpha$-naphtyl Fast blue RR salt, $\times 2000$ 

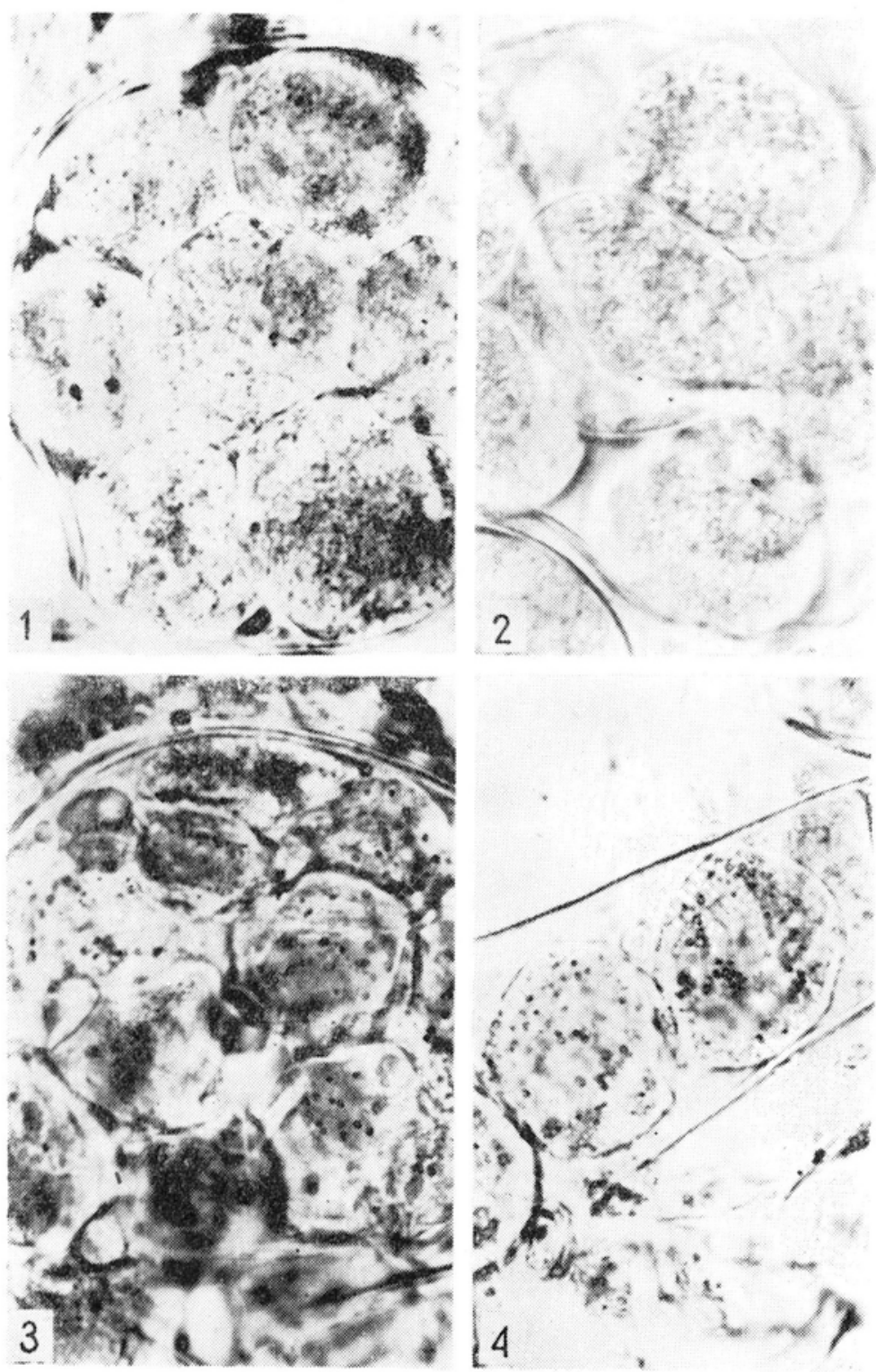

Localization of alkaline phosphatase in differentiated oogonia

Fig. 1. Formalin fixed, naphtol AS-BI phosphate, Fast blue RR salt, $\times 2000$ Fig. 2. Control in $\mathrm{HCl}, \times 2000$

Figs. 3, 4. Formalin - fixed, sodium a-naphtyl phosphate, Fast blue RR salt, $\times 2000$ 

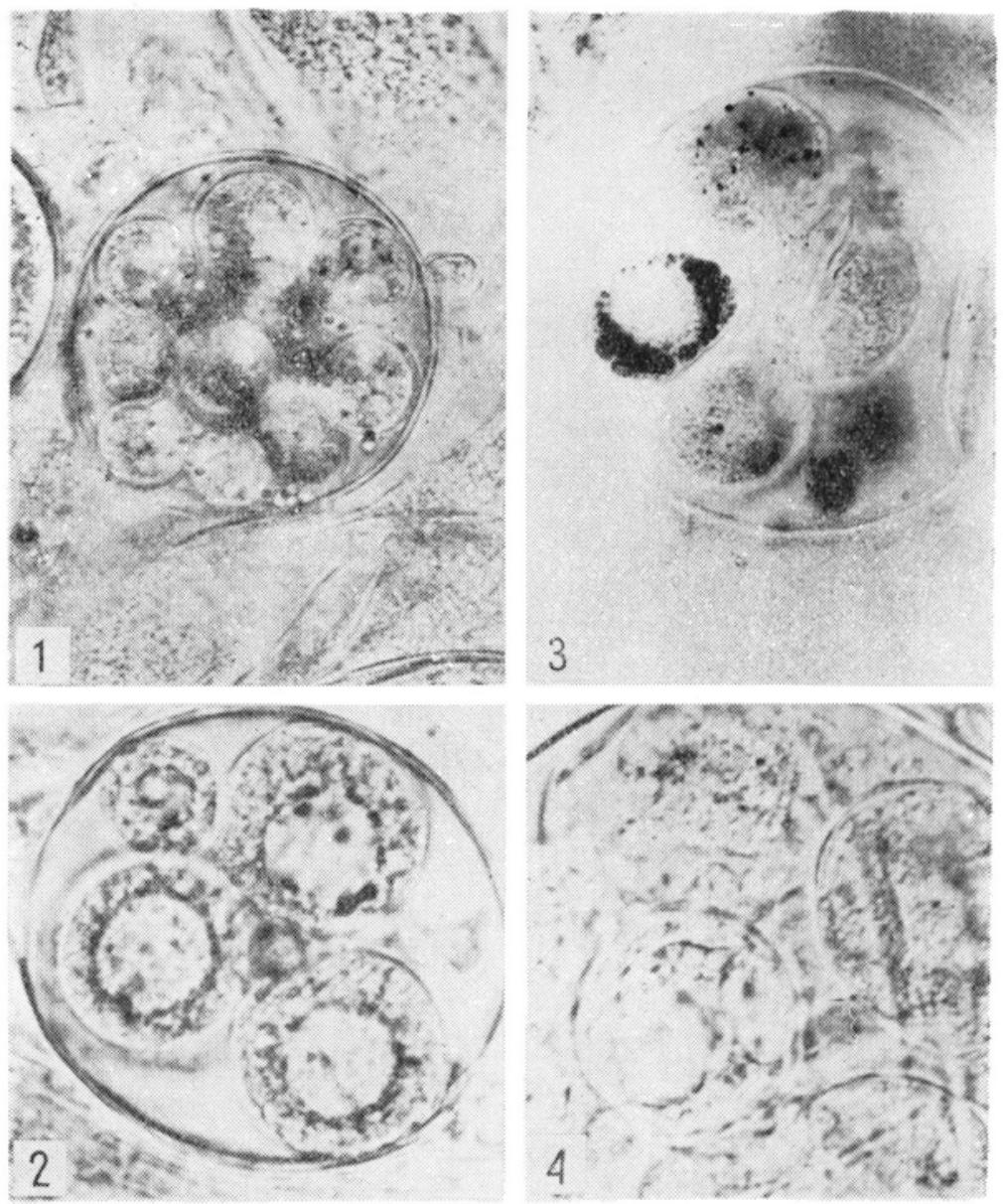

Localization of hydrolytic enzymes in differentiated oogonia

Figs. 1, 2. Indoxyl esterase, unfixed

Fig. 3. Acid phosphatase, formalin-fixed

Fig. 4. $\beta$-galactosidase, unfixed

Figs. 1, 3. magnified $\times 1500,2,4 \times 2000$ 
which are precursors of sporangia. After the formation of septa cutting off the sporangium a distinctive difference in the intensity of staining of the sporangia and the rest of the hyphae occurs.

Indoxyl esterase also shows higher activity in differentiating sporangia. In this case, however, the cytoplasm is stained as well as the spherosomes. The granules stained with indigo blue are small, distributed uniformly both in sporangia not showing yet fragmentation and during differentiation of the membranes surrounding the zoospores (Plate II, Figs. 9,11). Region of forming membranes occasionally stain blue (Plate II, Figs. 10,11). Preincubation of hyphae in $10^{-5}$ M. E 600 solution eliminated cytoplasmic staining in sporangia without affecting the intensity of spherosomes staining.

\section{Spores}

The intensity of the reaction for acid phosphatase is lower in spores than in the forming sporangium. The number of stained granules is different in particular spores. Sometimes staining of small regions of the cytoplasm occurs. The localization of indoxyl esterase, acid and alkaline phosphatase is the same (Plate III, Figs. 1,3,4). In control samples reaction gave a negative result (Plate II, Fig. 2). During germination no visible changes in the enzymatic equipment can be observed (Plate III, Figs. 5,6).

\section{Antheridial hyphae}

These hyphae surround oogonia and their outgrowths can sometimes be observed inside the oogonia. Their content resembles that of thin vegetative hyphae. Enzymes are localized in not very numerous granules (Plate IV, Figs. 2,5,6). Fragments of hyphae adjacent to oogonia often show an increased activity of acid phosphatase (Plate IV, Fig. 1), expressed also as staining of the cytoplasm.

\section{Oog on i a}

In the initial phase of differentiation the results of reactions are similar to those obtained in vegetative hyphae. In the young oogonia a visible vacuolization of the protoplast may be observed.

The reaction product appears by the membranes surrounding very small vacuoles (Plate IV, Figs. 2,5) or in the form of granules outside the vacuoles. Indigo blue deposit often accumulates in larger quantities in the layer of cytoplasm adjacent to the oogonial wall (Plate IV, Fig. 3). Inhibition of the activity by $10^{-3} \mathrm{M}$ sodium fluoride have yielded less 
intensely coloured reaction products. During differentiation the whole protoplast of the oogonium takes part in the formation of oospheres. Sometimes products of enzymatic reaction may be observed in the oogonia outside the oospheres (Plate VI, Fig. 1). These granular products are coming probably from the outgrowths of oogonial hyphae, which undergo lysis during the maturation of the fertilized oospheres.

The enzyme localization does not appear to be the same in all oospheres from one oogonium. This is especially notable in the case of acid phosphatase - in some oospheres deeply stained with the reaction product vacuoles and lipid droplets are visible (Plate VI, Fig. 3).

Indoxyl esterase gives a granular reaction products; a sligthly increased amount of indigo blue occurs on the surface of the lipid droplets, centrally located in the oospores (Plate VI, Fig. 2). In oogonia, similarly as in the vegetative hyphae, the number of granules which stained pale blue after applying the test for $\beta$-galactosidase was small (Plate VI, Fig. 4).

Alkaline phosphatase generally occurs in a small number of granules of similar dimensions (Plate V, Fig. 3,4), more rarely as a very small granulations (Plate V, Fig. 1). In control hyphae the reaction result is negative (Plate V, Fig. 2).

\section{DISCUSSION}

The present investigations have shown that indoxyl esterase, acid and alkaline phosphatase are detectable during the whole life cycle of Achlya flagellata.

In the case of $\beta$-galactosidase no positive results has been obtained regarding the spores.

All enzymes are mainly located in cytoplasmic granules $0,2-1 \mu$ in diameter. In vegetative hyphae the granules showing the presence of coloured products of enzymic reactions resemble by their size and distribution, the spherosomes observed in the living cells. The light and electron microscopic observations have shown that these granules may be considered as permanent components of vegetative hyphae ( $\mathrm{G} \mathrm{u}$ t z 1956; Palczewska 1964; Armentrout et al. 1968; Wilson et al. 1970), and sporangia (Wiliams and Webster 1970). The presence of both phosphatases in other cellular structures, i.e. in the dictyosomes and in the vacuoles is to be expected; this is suggested by some pictures of distribution of the reaction product in the vegetative hyphae and oogonia of Achlya. However, as there are no data on the localization of hydrolytic enzymes at the electron microscopes level, nor any information on the ultrastructure of sexual reproductive cells, it is difficult to discuss this subject in a more detailed way. 
The results of enzymic reactions obtained in the vegetative hyphae of Achlya flagellata are comparable with the data of Pit and Walker (1967) and Pitt (1968) for Botrytis cinerea, and those of Wilson and al. (1970) for several species of fungi belonging to various taxonomic groups. W a lker and Pitt (1967) and Pit t (1968) demonstrated the presence of acid phosphatase, esterases and $\beta$-galactosidase within cytoplasmic particles, which they consider to be counterparts of animal lysosomes. Similarly Wils on et al. (1970) detected acid phosphatase in lysosomes like structures. According to R e is s (1968), who worked on Neurospora and Aspergillus, the distribution of $\beta$ galactosidase gives no clue as to the site of its activity.

The results of cytochemical investigations on the occurrence of $\beta$-galactosidase are controversial. This may be caused by differences in the occurrence of this enzyme in various species of fungi, and may also be due to the use of different media for fungal cultures. Biochemical tests have shown ( $\mathrm{Z}$ a lok a r 1959; K e e n 1970; K e e n et al. 1970) that $\beta$-galactosidase is an inducible enzyme: it was detected in fungi growing on lactose medium. Reiss (1969) used lactose in his media, but Pitt (1968) cultivated Botrytis on malt agar. In both cases the activity of the enzyme was higher than that observed for Achlya mycelium, which has grown on natural medium (hemp seeds).

Differences in results of enzymic reactions also occur if different methods are used. Thus R e is s (1969) did not obtain positive reactions in Neurospora crassa and Aspergillus oryzae using 6-bromo-2-naphtyl- $\beta$-D-galactopyranoside and postcoupling with Fast blue B salt, even though this method gave positive results for Botrytis and Achlya hyphae. He obtained excellent results however, using nitro BT according to Lojda (1965, quoted after $R$ eiss 1969).

In differentiating sporangia a high acid phosphatase and a sligthly lower indoxyl esterase activities can be observed. The occurrence of higher activity of these enzymes in sporangia depends on the existence of hydrolytic processes. Electron micrographs have already given someinformation on the ultrastructure of sporangia. Williams and Webster (1970) observed in Phytophtora capsici sporangia changes in osmiophilic bodies, leading to the formation of the electron transparent bodies. In a morfologically similar system, namely during the ascosporogenesis in Ceratocystis fimbriata, Wils on et al. (1970) noted that the contents of lysosomes, which are the structures containing hydrolytic enzymes, are emptied out. The authors assume that enzymes liberated from lysosomes hydrolise the part of protoplast which does not participate in ascospore formation.

The observations of Nilsson (1962) and Fux and Nilsson (quoted after Strauss 1967 p. 285), performed on uterine epitelium 
of spayed mice, show that acid phosphatase may participate in the degradation of phosphatides and esterase in glicerides degradation. The occurrence of both processes in sporangia is to be expected.

Alkaline phosphatase is the only one of the enzymes investigated in Achlya flagellata which has not been yet cytochemically detected in other fungal cells. Biochemical tests (Mc Lellon, Lampen 1963 and Tonino, Steyn-Parvé 1963 in yeasts, Davis and Lees 1969 in Neurospora, Lo o m is 1969 in Dictyostelium discoideum) have shown that this enzyme may be induced and that the proportion of it detected in soluble and particulate cellular fractions varies depending on the age of yeast cells. During the development of Dictyostelium (L o o$\mathrm{m}$ is 1969) a dramatic increase of enzyme activity takes place at the stage of plasmodium culmination. The author considers that two proteins showing alkaline phosphatase activity occur in this organism.

No noticeable changes in alkaline phosphatase activity were observed during the development cycle of Achlya flagellata.

As can be seen from the data presented, no information is available in the literature on the localization of hydrolytic enzymes in sexual reproductive cells. The only data on this subject are supplied by Turian (1958) concerning the localization of acid and alkaline phosphatases in Allomyces gametes. The distribution of the two enzymes is identical, but on the basis of this work, it is difficult to judge in which structures these enzymes were localized.

The authors wish to thank Miss Elżbieta Tober, M.Sc. for advice on the isolation and initial culture of aquatic fungi and for identyfying the isolated species. We express our gratitude to Professor Maria Olszewska for discussion on the manuscript.

\section{REFERENCES}

Armentrout V.A., Smith G.G., Wils on H.L., 1968, Spheresomes and mitochon̄̄ria in the living fungal cell, Amer.J.Bot. 55: 1062-1067.

B u c kl e y P.M., Som m e r N.F., M a t s u m o to T.T., 1968, Ultrastructural details in germinating sporangiospores of Rhizopus stolonifer and Rhizopus arrchizus, J. Bacteriol. 95: 2365-2373.

Davis F.W.J., Lees How ard, 1969, Alkaline phosphatases of Neurospora crassa Part I, J. Microbiol. 15: 455-459.

Gutz H., 1956, Zur Analyse der Granula-Fluorochromierung mit Nilblau in den Hyphen von Mucor recemosus Fres., Planta 46: 481-511.

G ün the r T.H., K a t t n e r W., M erker H.J., 1967, Ưber das Verhalten und die Lokalisation der sauren Phosphatase von Hefezellen bei Repression und Derepression, Exp. Cell Res. 45: 133-147.

Iten W., Matile P., 1970, Role of chitinase and other lysosomal enzymes of Coprinus lagopus in the autolysis of fruiting bodies, J.Gen.Microbiol. 61: 301-309. 
Keen N.T., 1970, Properties of $\beta$-galactosidase from Verticillium albo-atrum, Physiol.Plant. 23: 878-888.

Ke en N.T., Long M., Malca I., 1970, Induction and repression of $\beta$-galactosidase synthesis by Verticillium albo-atrum, Physiol. Plant. 23: 691-696.

Loomis W.F. JR., 1969, Developmental regulation of alkaline phosphatase in Dictyostelium discoideum, J. Bacteriol. 100: 417-422.

M a tile P., Wi emken A., 1967, The vacuole as the lysosome of the yeast cell, Archiv f. Mikrobiol. 56: 148-157.

McLellon W.L., Lampen J.O., 1963, The acid phosphatase of yeast: localization and secretion by protoplasts, Bioch.Biophys.Acta 67: 324-326.

M edzon E.L., Brady M.L. 1969, Direct measurement of acertylesterase in living protist cells, J. Bacteriol. 97: 402-415.

PalczewskaI., 1964, Badania cytomorfologiczne i cytochemiczne grzybni Polyporus sulphureus Bull. et Fr., Zeszyty Naukowe Uniw. Éódzkiego, ser. II 16: $151-161$.

Palczewska I., 1965, Uber die Lokalisierung der Thiaminpyrophosphatase in den Hyphen von Achlya sp. Acta Soc.Bot.Pol. 34: 753-756.

Pearse A.G.E., 1961, Histochemistry theoretical and applied, J.A.Churchill Ltd., London.

Pitt D., 1968, Histochemical demonstration of certain hydrolytic enzymes within cytoplasmic particles of Botrytis cinerea Fr, J.Gen.Microbiol. 52: 67-75.

Pitt D., Walker P.J., 1967, Particulate localization of acid phosphatase in fungi, Nature, Lond. 215: 783-784.

Reiss J., 1969, Cytochemischer Nachweis von Hydrolasen in Pilzzellen, Histochemie 18: $12-23$.

S tr a u s W., 1967, Lysosomes, phagosomes and related particles in Enzyme cytology, (ed. D.B. Roodyn) Academic Press, London 239-319.

T on in o G.J.M., S te y n-P a rvé E.P. 1963, Localization of some phosphatases in yeast, Biochim.Biophys.Acta 67: 453-469.

Turian G., 1958, Recherches sur les bases cytochimiques et cytophysiologiques de la morphogenèse chez le champignon aquatique Allomyces, Rev.Cytol.Biol.. Végét. 19: $241-272$.

Williams W.T., Webster R.K., 1970, Electron microscopy of the sporangium of Phytophtora capsici, Canad.J.Bot. 48: 221-227.

W il s o n Ch.L., S tier s D.L., S m i th G.S., 1970, Fungal lysosomes or spherosomes, Phytopatology 61: 216-227.

$\mathrm{Z}$ a lok a r M., 1959, Enzyme activity and cell differentiation in Neurospora, Amer. J.Bot. 46: 555-559.

\section{Lokalizacja niektórych enzymów hydrolitycznych $w$ różnych stadiach rozwojowych grzybni Achlya flagellata}

\section{Streszczenie}

Stosując metody sprzęgania $\mathrm{z}$ barwnikami azowymi zbadano aktywność esterazy indoksylowej, kwaśnej fosfatazy, zasadowej fosfatazy i $\beta$-galaktozydazy w cyklu wegetatywnym i płciowym Achlya flagellata.

Kwaśna fosfataza jest enzymem dominującym podczas tworzenia się zarodni, jeszcze przed powstaniem przegrody oddzielającej zarodnię od reszty strzępki. Mniejszą aktywność wykazuje w tym stadium esteraza indoksylowa. 
Zasadowa fosfataza jest enzymem charakterystycznym dla młodych części grzybni.

Aktywność $\beta$-galaktozydazy jest najniższa. W zarodnikach wyniki reakcji były negatywne.

W zarodnikach obrazy lokalizacji esterazy oraz kwaśnej i zasadowej fosfatazy są identyczne.

Oosfery i oospory nie wyróżniają się wybitniejszą aktywnością żadnego z przebadanych enzymów.

Procesy hydrolityczne są uintensywnione w stępkach plemniowych oraz w degenerujących oosferach, w których występują wakuole trawienne.

Produkty reakcji enzymatycznej, z wyjątkiem esterazy E 600 wyrażliwej, wykazującej lokalizację cytoplazmatyczną, były zlokalizowane w ziarnistościach cytoplazmatycznych o średnicy $0,2-1 \mu$. Obrazy rozmieszczenia aktywności enzymatycznej sugerują, że produkt reakcji jest zawarty głównie w sferosomach. 